
MANAGEMENT, AND ACCOUNTING

Fakultas Ekonomi Universitas Andi Djemma

Jl. Puang H. Daud No 4 Kota Palopo

\title{
Analisis Kinerja Keuangan Kabupaten Toraja Utara Tahun 2017-2018
}

\section{Penulis}

\section{Jemi Pabisangan Tahirs}

Universitas Kristen Indonesia Toraja

Email: tahirsjemi@gmail.com

\author{
Info Artikel \\ p-ISSN : 2615-1871 \\ e-ISSN : 2615-5850 \\ Volume 3 Nomor 1, Maret 2020 \\ DOI: \\ http://dx.doi.org/10.35914/jemma.v3i1.329 \\ Article History: \\ Received, 4 Februari 2020 \\ Revised, 16 Februari 2020 \\ Accepted, 16 Maret 2020
}

\begin{abstract}
ABSTRAK
Pengelolaan keuangan daerah adalah bagian dari sistem pengelolaan keuangan Negara. Pemerintah Daerah dalam mengelola keuangan daerah dituntut menggunakan keuangan daerah secara efisien penggunaanya sesuai kebutuhan. Keuangan Daerah merupakan salah satu indikator dalam mengukur kemampuan daerah dalam melaksanakan otonomi dan upaya mendapatkan dana dan penggunaannya sesuai potensi yang dimiliki daerah. Penelitian ini dilakukan untuk mengetahui kinerja keuangan pemerintah daerah Kabupaten Toraja Utara. Penelitian ini merupakan penelitian deskriptif kuantitatif. Pengumpulan data menggunakan metode wawancara dan dokumentasi. Teknik analisis data yang digunakan deskriptif kuantitatif dengan rumus: Rasio Kemandirian Keungan Daerah, Rasio Efektifitas PAD, Rasio Efisiensi Keuangan Daerah, Rasio Aktivitas, dan Rasio Pertumbuhan. Hasil analisis menunjukkan bahwa Kinerja Keuangan BPKAD Kabupaten Toraja Utara dilihat dari Rasio Kemandirian keuangan daerah masih rendah yang berarti bahwa peran pemerintah pusat lebih dominan daripada kemendirian pemerintah daerah, Rasio Efektivitas PAD masih tergolong belum efektif yang menandakan pencapaian penerimaan PAD tidak sesuai dengan yang ditargetkan, Rasio Efisieansi Keuangan Daerah masih tergolong belum efisien, Rasio Aktivitas Belanja Operasi tergolong baik sedangkan Rasio Belanja Modal tergolong belum baik artinya pemerintah daerah Kabupaten Toraja Utara masih mengalokasikan sebagian besar belanjanya pada belanja operasi, Rasio Pertumbuhan Pendapatan menunjukkan pertumbuhan yang masih tergolong rendah yaitu di bawah 12,98\%.
\end{abstract}

Kata Kunci: Rasio Keuangan Daerah, Kinerja Keuangan.

\section{PENDAHULUAN}

UU No. 32 tahun 2004 tentang Pemerintah Daerah dan UU No. 33 tahun 2004 tentang perimbangan keuangan antara Pemerintah Pusat dan Pemerintah Daerah memberikan gambaran pengelolaan keuangan daerah. Dengan Undang-Undang ini memberikan kewenangan bagi pemerintah daerah dalam mengelola sumber daya yang dimilikinya secara efektif dan efisien. Pengelolaan keuangan daerah secara transparansi dan akuntabilitas akan menjamin penggunaan sumber daya, arah dan tujuan serta penggunaan anggaran. Dengan 
transparansi, masyarakat dapat mengetahui secara jelas kebijakan dan tindakan yang diambil pemerintah daerah dalam penggunaan sumber daya yang dimiliki. Sedangkan akuntabilitas adalah bentuk pertanggungjawaban dalam mencapai tujuan dan sasaran yang ditetapkan berhasil atau gagal.

Pengelolaan keuangan daerah adalah bagian dari sistem pengelolaan keuangan Negara. Pemerintah Daerah dalam mengelola keuangan daerah dituntut menggunakan keuangan daerah secara efisien penggunaanya sesuai kebutuhan. Keuangan Daerah merupakan salah satu indikator dalam mengukur kemampuan daerah dalam melaksanakan otonomi dan upaya mendapatkan dana dan penggunaannya sesuai potensi yang dimiliki daerah.

Keuangan daerah menggambarkan pendapatan/penerimaan daerah dan belanja/pengeluaran daerah. Pendapatan Daerah adalah arus masuk bruto manfaat ekonomi dalam satu periode dan berdampak pada kenaikan ekuitas dan bukan dari pengembalian pinjaman (Indra Bastian\&Gatot Soepriyanto, 2003). Sedangkan Pengeluaran Daerah adalah penurunan manfaat ekonomi dalam satu periode berupa kas keluar/deplesi aset dan berkurangnya ekuitas dana sebagai akibat utang (Halim, 2002). Proses pengelolaan keuangan daerah meliputi perencanaan atau penyusunan anggaran yang tertuang dalam APBD. Anggaran Pendapatan Belanja Daerah (APBD) merupakan rencana keuangan tahunan pemerintahan daerah yang dibahas dan disetujui bersama oleh Pemerintah Daerah dengan DPRD dan ditetapkan dengan Peraturan Daerah.

Badan Pusat Statistik (2019:1) Kabupaten Toraja Utara memiliki luas wilayah $1.151,47 \mathrm{~km}^{2}$ dan jumlah penduduk sebanyak 229.797 jiwa. Sebagai Kabupaten pemekaran dari Kabupaten Tana Toraja, Kabupaten Toraja Utara memiliki tugas dalam mengelola pemerintahan ke arah yang lebih baik dan meningkatkan kinerja keuangan. Pemerintah Kabupaten Toraja Utara dituntut untuk dapat mengelola APBD secara baik agar arah dan tujuan pembangunan dapat tercapai.

Tabel 1. Laporan Realisasi APBD Kabupaten Toraja Utara tahun 2017

\begin{tabular}{|l|l|r|r|c|}
\hline No. & \multicolumn{1}{|c|}{ Uraian } & \multicolumn{1}{c|}{ Anggaran (Rp) } & \multicolumn{1}{c|}{ Realisasi (Rp) } & \% \\
\hline 1. & Pendapatan & $970.110 .105 .000,00$ & $937.099 .748 .186,12$ & 95,60 \\
\hline 2. & Pendapatan Asli Daerah & $66.508 .803 .000,00$ & $44.165 .976 .209,12$ & 66,41 \\
\hline 3 & Belanja & $1.177 .080 .972 .368,00$ & $930.420 .467 .071,32$ & 74,04 \\
\hline
\end{tabular}

Sumber: BPKAD Kabupaten Toraja Utara tahun2017.

Tabel 2. Laporan Realisasi APBD Kabupaten Toraja Utara Tahun 2018

\begin{tabular}{|l|l|r|r|c|}
\hline No. & \multicolumn{1}{|c|}{ Uraian } & \multicolumn{1}{c|}{ Anggaran (Rp) } & \multicolumn{1}{c|}{ Realisasi (Rp) } & \% \\
\hline 1. & Pendapatan & $1.120 .005 .844 .237,00$ & $1.058 .775 .411 .390,30$ & 94,53 \\
\hline 2. & Pendapatan Asli Daerah & $71.697 .072 .540,00$ & $52.714 .824 .265,30$ & 73,52 \\
\hline $3 .$. & Belanja & $1.131 .239 .059 .515,70$ & $1.027 .592 .287 .967,00$ & 90,84 \\
\hline
\end{tabular}

Sumber: BPKAD Kabupaten Toraja Utara tahun 2018.

Laporan realisasi anggaran tahun 2017 secara keseluruhan memperlihatkan bahwa anggaran pendapatan sebesar $\mathrm{Rp} 970.110 .105 .000,00$ dan realisasinya sebesar Rp937.099.748.186,12 atau 95,60\%. Selanjutnya untuk tahun 2018 anggaran pendapatan sebesar $\mathrm{Rp}$ 1.120.005.844.237,00 dan realisasi pendapatan $\mathrm{Rp1}$ 1.058.775.411.390,30 atau 94,53\%. Secara keseluruhan dapat dilihat bahwa pendapatan setiap tahunnya menunjukkan kenaikan. Apabila dilihat dari pendapatan asli daerah dimana anggaran pendapatan yang ditetapkan tahun 2017 sebesar Rp $\quad 66.508 .803 .000,00$ dan realisasinya $\mathrm{Rp}$ 44.165.976.209,12 atau 66,41\%. Untuk tahun 2018 anggaran pendapatan dari Pendapatan Asli Daerah sebesar $\mathrm{Rp} 71.697 .072 .540,00$ dan realisasinya sebesar Rp 52.714.824.265,30 atau 73,52\%. Bila dibandingkan dengan realisasi belanja dimana anggaran tahun 2017 ditetapkan sebesar 
Rp1.177.080.972.368,00 dan realisasi belanja sebesar Rp 930.420.467.071,32 nampak bahwa belanja masih lebih kecil dari pendapatan. Sedangkan belanja tahun 2018 dimana anggaran belanja yang ditetapkan sebesar $\mathrm{Rp}$ 1.131.239.059.515,70 dan realisasi belanja sebesar Rp1.027.592.287.967,00 masih dibawah total realisasi pendapatan. Dari laporan keuangan memperlihatkan bahwa pengeluaran masih dibawah dari pendapatan. Tujuan penelitian ini untuk mengetahui kinerja keuangan pemerintah daerah Kabupaten Toraja Utara dengan rasio kemandirian keuangan pemerintah daerah (RKKD), rasio efektivitas PAD (Pendapatan Asli Daerah), rasio efisiensi keuangan daerah, rasio aktifitas dan rasio pertumbuhan.

\section{METODE PENELITIAN}

\section{Jenis Penelitian}

Jenis penelitian yang digunakan adalah penelitian kuantitatif. Data kuantitatif adalah analisis RKKD, Rasio Efektivitas PAD, Rasio Efisiensi Keuangan Daerah, Rasio Aktivitas, dan Rasio Pertumbuhan.

\section{Jenis Data dan Sumber data}

Jenis data terdiri dari data primer dan data sekunder. Data primer adalah data yang diperoleh secara langsung pada Pemerintah Kabupaten Toraja Utara melalui wawancara. Sedangkan data sekunder adalah data yang diperoleh dari literatur, buku dan referensi yang berkaitan dengan penelitian ini.

\section{Metode Pengumpulan Data}

Prosedur pengumpulan dilakukan dengan observasi, wawancara dan dokumentasi dengan staf pemerintah Kabupaten Toraja Utara. Metode yang digunakan adalah

1. Observasi, yaitu pengumpulan data dengan cara mengadakan pengamatan secara langsung.

2. Wawancara, yaitu pengumpulan data dengan mengajukan pertanyaan secara langsung kepada pimpinan dan pegawai Pemerintah Kabupaten Toraja Utara.

3. Dokumentasi, yaitu pengumpulan data dengan mengumpulkan dokumen-dokumen serta arsip yang ada kaitannya dengan masalah yang akan dibahas.

\section{Metode Analisis}

Penelitian ini menggunakan metode deskriptif kuantitatif. Metode ini yaitu dengan mengumpulkan data, disusun, diinterprestasikan, dan dianalisis sehingga memberikan kesimpulan yang jelas dan objektif terhadap masalah yang ada yaitu mengenai kinerja keuangan Pemerintah Kabupaten Kepulauan Sangihe dengan menggunakan metode value for money, yaitu dilihat dari segi ekonomis, efisiensi dan efektifitas penggunaan anggaran. Untuk mengukur kinerja secara ekonomis digunakan formula sebagaimana diuraikan dalam tinjauan pustaka oleh Mahmudi (2011:21) yaitu: adapun teknik analisis data dalam penelitian ini adalah:

Untuk mengukur kinerja keuangan dari Rasio Kemandirian Keuangan Daerah (RKKD) (Halim, 2007) yaitu :

$\mathrm{RKKD}=\frac{\mathrm{PAD}}{\text { Pendapatan Transfer }} \mathrm{X} 100 \%$

Untuk mengukur kinerja keuangan dari Rasio Efektivitas (Mahmudi, 2010) yaitu :

Rasio Efektivitas $=\frac{\text { Realisasi PAD }}{\text { Anggaran PAD }} \times 100 \%$ 
Untuk mengukur kinerja keuangan dari Rasio efisiensi (Halim, 2007) yaitu :

Rasio Efisiensi $=\frac{\text { Realisasi Belanja Daerah }}{\text { Realisasi Pendapatan Daerah }}$ X 100\%

Untuk mengukur kinerja keuangan dari Rasio Aktivitas (Halim, 2007) yaitu :

Rasio Belanja Operasi $=\frac{\text { Total Belanja Operasi }}{\text { Total Belanja Daerah }}$ X 100\%

Rasio Belanja Modal $=\frac{\text { Total Belanja Modal }}{\text { Total Belanja Daerah }}$ X 100\%

Untuk mengukur kinerja keuangan dari Rasio Pertumbuhan (Halim, 2007) yaitu:

$$
\mathrm{r}=\frac{P n-P 0}{P 0} \times 100 \%
$$

Keterangan :

$\mathrm{r} \quad=$ Rasio Pertumbuhan

Pn $=$ Total Pendapatan Daerah/ PAD/ Belanja Modal/ Belanja Operasi yang dihitung pada tahun ke-n

P0 = Total Pendapatan Daerah/ PAD/ Belanja Modal/ Belanja Operasi yang dihitung pada tahun ke-0 (tahun sebelum $\mathrm{n}$ )

\section{HASIL DAN PEMBAHASAN}

\section{Hasil Penelitian}

\section{Kinerja Keuangan tahun 2017 dan tahun 2018}

Kinerja Keuangan dari Rasio Kemandirian Keuangan Daerah (RKKD) tahun 2017

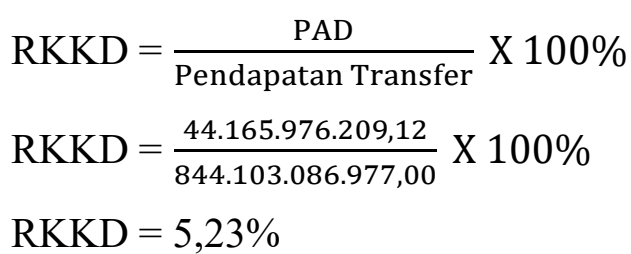

Kinerja Keuangan dari Rasio Kemandirian Keuangan Daerah (RKKD) tahun 2018

$$
\begin{aligned}
& \text { RKKD }=\frac{\text { PAD }}{\text { Pendapatan Transfer }} \times 100 \% \\
& \text { RKKD }=\frac{52.714 .824 .265,30}{949.917 .395 .093,00} \times 100 \% \\
& \text { RKKD }=5,54 \% .
\end{aligned}
$$

Kinerja Keuangan dari Rasio Efektivitas PAD tahun 2017

Rasio Efektifitas $=\frac{\text { Realisasi PAD }}{\text { Anggaran PAD }}$ X 100\%

Rasio Efektifitas $=\frac{44.165 .976 .209,12}{66.508 .803 .000,00} \times 100 \%$

Rasio Efektivitas $=66,41 \%$.

Kinerja Keuangan dari Rasio Efektivitas PAD tahun 2018

Rasio Efektifitas $=\frac{\text { Realisasi PAD }}{\text { Anggaran PAD }}$ X 100\% 
Rasio Efektifitas $=\frac{52.714 .824 .265,30}{71.697 .072 .540,00} \times 100 \%$

Rasio Efektivitas $=73,52 \%$.

Kinerja Keuangan dari Rasio Efisiensi tahun 2017

Rasio Efisiensi $=\frac{\text { Realisasi Belanja Daerah }}{\text { Realisasi Pendapatan Daerah }}$ X 100\%

Rasio Efisiensi $=\frac{930.420 .467 .071,32}{937.099 .748 .186,12}$ X 100\%

Rasio Efisiensi $=99,28 \%$

Kinerja Keuangan dari Rasio Efisiensi tahun 2018

Rasio Efisiensi $=\frac{\text { Realisasi Belanja Daerah }}{\text { Realisasi Pendapatan Daerah }}$ X 100\%

Rasio Efisiensi $=\frac{1.027 .592 .287 .967,00 \mathrm{~h}}{1.058 .775 .411 .390,30} \times 100 \%$

Rasio Efisiensi $=97,05 \%$

Kinerja Keuangan dari Rasio Aktivitas tahun 2017

Rasio Belanja Operasi $=\frac{\text { Total Belanja Operasi }}{\text { Total Belanja Daerah }}$ X 100\%

Rasio Belanja Operasi $=\frac{716.616 .718 .403,00}{930.420 .467 .071,32}$ X 100\%

Rasio Belanja Operasi $=77,02 \%$

Rasio Belanja Modal $=\frac{\text { Total Belanja Modal }}{\text { Total belanja Daerah }}$ X 100\%

Rasio Belanja Modal $=\frac{211.570 .489 .218,32}{930.420 .467 .071,32} \times 100 \%$

Rasio Belanja Modal $=22,73 \%$

Kinerja Keuangan dari Rasio Aktivitas tahun 2018

Rasio Belanja Operasi $=\frac{\text { Total Belanja Operasi }}{\text { Total Belanja Daerah }}$ X 100\%

Rasio Belanja Operasi $=\frac{806.947 .469 .422,00}{1.027 .592 .287 .967,00} \times 100 \%$

Rasio Belanja Operasi $=78,52 \%$

Rasio Belanja Modal $=\frac{\text { Total Belanja Modal }}{\text { Total belanja Daerah }}$ X 100\%

Rasio Belanja Modal $=\frac{216.253 .328 .945,00}{1.027 .592 .287 .967,00}$ X 100\%

Rasio Belanja Modal $=21,04 \%$

Kinerja Keuangan dari Rasio Pertumbuhan Pendapatan tahun 2017

Rasio Pertumbuhan pendapatan $=\frac{\mathrm{Pn}-\mathrm{P} 0}{\mathrm{P} 0} \times 100 \%$

Rasio Pertumbuhan pendapatan $=\frac{937.099 .748 .186,12-873.277 .459 .288,95 \mathrm{P} 0}{873.277 .459 .288,95} \mathrm{X} 100 \%$ 
Rasio Pertumbuhan pendapatan $=7,30 \%$

Kinerja Keuangan dari Rasio Pertumbuhan tahun 2018

Rasio Pertumbuhan $=\frac{\mathrm{Pn}-\mathrm{P} 0}{\mathrm{P} 0} \times 100 \%$

Rasio Pertumbuhan pendapatan $=\frac{1.058 .775 .411 .390,30-937.099 .748 .186,12}{937.099 .748 .186,12}$ X 100\%

Rasio Pertumbuhan pendapatan $=12,98 \%$

Tabel 3 Hasil pengukuran Kinerja keuangan dengan metode rasio keuangan

\begin{tabular}{|l|c|c|}
\hline \multicolumn{1}{|c|}{ Pengukuran } & Tahun 2017 (\%) & Tahun 2018 (\%) \\
\hline Rasio Kemandirian Kuangan Daerah & 5,23 & 5,54 \\
Rasio Efektivitas & 66,41 & 73,52 \\
Rasio Efisiensi Keuangan Daerah & 99,28 & 97,05 \\
Rasio Aktivitas Belanja Operasi & 77,02 & 78,52 \\
Rasio Aktivitas Belanja Modal & 22,73 & 21,04 \\
Rasio Pertumbuhan Pendapatan & 7,30 & 12,98 \\
\hline
\end{tabular}

Sumber : Data olahan tahun 2018

\section{Pembahasan}

\section{Rasio Kemandirian Keuangan Daerah (RKKD)}

Berdasarkan hasil perhitungan RKKD Kabupaten Toraja Utara pada tahun 2017 sebesar 5,23\% dan tahun 2018 sebesar 5,54\%. Hal ini diakibatkan oleh pendapatan transfer dari pemerintah pusat jauh lebih besar dari PAD Kabupaten Toraja Utara yaitu pada tahun 2017 sebesar Rp. 799.529.032.149,00 atau 85,31\% dari total pendapatan sedangkan PAD sebesar Rp. 52.714.824.265,30 atau 4,71\% dari total pendapatan. Pada tahun 2018 pendapatan transfer dari pemerintah pusat sebesar Rp.905.506.344.613,00 atau 85,52\% dari total pendapatan sedangkan PAD sebesar Rp.52.714.824.265,30 atau 4,97\% dari total pendapatan.

Hal tersebut menunjukkan bahwa tingkat kemandirian daerah Kabupaten Toraja Utara masih sangat rendah yang berarti bahwa peran pemerintah pusat lebih dominan daripada kemandirian daerah Kabupaten Toraja Utara.

\section{Rasio Efektivitas PAD}

Dari hasil perhitungan Rasio Efektivitas PAD menunjukkan bahwa Anggaran PAD dari tahun 2017 ke tahun 2018 mengalami peningkatan yaitu pada tahun 2017 sebesar Rp.66.508.803.000,00 atau 6,8\% dari total anggaran pendapatan dan pada tahun 2018 sebesar Rp.71.697.072.540,00 atau 6,4\% dari total anggaran pendapatan.

Realisasi PAD pada tahun 2017 sampai tahun 2018 juga mengalami peningkatan yaitu pada tahun 2017 sebesar Rp. 44.165.976.209,12 atau 4,7\% dari total pendapatan dan pada tahun 2018 sebesar Rp.52.714.824.264,30 atau 4,9\% dari total pendapatan.

Rata-rata rasio efektivitas PAD Kabupaten Toraja Utara sebesar 69,96\% dan tergolong tidak efektif. Hal ini karena kurangnya realisasi pendapatan pajak daerah yang disebabkan oleh kurangnya kesadaran wajib pajak dalam membayar pajak serta kurangnya ketegasan petugas terhadap wajib pajak. Kurangnya kesadaran masyarakat dalam membayar pajak disebabkan karena masyarakat belum memahami tentang penggunaan uang pajak itu sendiri. Pendapatan retribusi daerah dan lain-lain PAD yang sah yang belum terealisasi sepenuhnya disebabkan karena target anggaran yang terlalu tinggi. 


\section{Rasio Efisiensi Keuangan Daerah}

Hasil perhitungan rasio efisiensi keuangan daerah diketahui bahwa rata-rata rasio efisiensi keuangan daerah Kabupaten Toraja Utara adalah sebesar 98,16\% yang termasuk dalam kategori kurang efisien. Realisasi belanja daerah pada tahun 2017 sebesar Rp930.420.467.071,32 dan realisasi pendapatan sebesar Rp.937.099.748.186,12. Pada tahun 2018 Realisasi belanja daerah sebesar Rp.1.027.592.287.967,00 dan realisasi pendapatan sebesar Rp.1.058.775.411.390,30 hal tersebut menunjukkan bahwa pendapatan daerah meningkat namun juga diikuti oleh peningkatan belanja daerah yang menandakan bahwa pemerintah daerah belum mampu menekan belanja daerahnya.

\section{Rasio Aktivitas}

Dari perhitungan rasio aktivitas diketahui bahwa sebagian besar belanja daerah dialokasikan pada belanja operasi yaitu sebesar 77,02\% pada tahun 2017 dan 78\%,52 pada tahun 2018. 22.73\% pada tahun 2017 dan 21,04 pada tahun 2018 dialokasikan pada belanja modal.

Sebagian besar belanja operasi dialokasikan pada belanja pegawai yaitu pada tahun 2017 Rp. 330.559.694.156,00 atau 46,13\% dari total belanja operasi dan pada tahun 2018 sebesar Rp.345.303.934.663,00 atau 42,79\% dari total belanja operasi. Dari hal tersebut dapat diketahui bahwa belanja untuk pegawai lebih besar daripada belanja modal yang berarti bahwa Pemerintah Daerah Kabupaten Toraja Utara lebih condong kepada belanja aktivitas pemerintahan dibandingkan pembangunan daerah.

\section{Rasio Pertumbuhan Pendapatan}

Dari hasil perhitungan dapat diketahui bahwa pertumbuhan pendapatan pada tahun 2017 sebesar 7,30\% dan pada tahun 2018 naik yaitu sebesar 12,98\% namun masih tergolong rendah.Hal ini diakibatkan oleh adanya pertumbuhan pada setiap komponen pendapatan namun masih rendah.

\section{SIMPULAN DAN SARAN}

\section{Simpulan}

Sesuai dengan hasil analisis data dan pembahasan yang telah dikemukakan sebelumnya dalam penelitian ini maka dapat diambil kesimpulan sebagai berikut:

1. Kinerja Keuangan Pemerintah Daerah Kabupaten Toraja Utara dari Rasio Kemandirian Keuangan Daerah dalam memenuhi kebutuhan dana untuk menyelenggarakan tugas pemerintahan, pembangunan, dan pelayanan masyarakat masih relatif rendah yang berarti peran pemerintah pusat lebih dominan daripada pemerintah daerah.

2. Kinerja Keuangan Pemerintah Daerah Kabupaten Toraja Utara dari Rasio Efektivitas PAD tergolong tidak efektif akibat kurangnya pendapatan pajak, pendapatan retribusi, dan lain-lai PAD yang sah.

3. Kinerja Keuangan Pemerintah Daerah Kabupaten Toraja Utara dari Rasio Efisiensi Keuangan Daerah tergolong tidak efisien akibat tingginya belanja daerah yang hampir menyamai pendapatan. Artinya pemerintah daerah belum mampu mengendalikan penggunaan anggaran secara efisien.

4. Kinerja Keuangan Pemerintah Daerah Kabupaten Toraja Utara dari Rasio Aktivitas alokasi dana masih dominan mengalokasikan belanja operasi daripada belanja modal. Hal tersebut diakibatkan oleh pemerintah daerah yang masih berkonsentrasi pada pemenuhan belanja operasi.

5. Kinerja Keuangan Pemerintah Daerah Kabupaten Toraja Utara dari Rasio Pertumbuhan pendapatan masih tergolong rendah hal ini terjadi karena komponen pendapatan masih rendah. 


\section{Saran}

Bagi Pemerintah Daerah Kabupaten Toraja Utara diharapkan untuk:

1. Mengoptimalkan potensi daerah yang menjadi sumber PAD

2. Melakukan efisiensi penggunaan anggaran sesuai kebutuhan.

\section{DAFTAR PUSTAKA}

Adhiyantoko, H. 2013. Analisis Kinerja Keuangan Pemerintah Kabupaten Blora (Studi Kasus pada Dinas Pendapatan Pengelolaan Keuangan dan Aset Daerah Kabupaten Blora Tahun 2007-2011). Skripsi (Online) (https://repository.usd.ac.id) Diakses 15 Oktober 2019.

Badan Pusat Statistik Kabupaten Toraja Utara. 2019.

Bastian, Indra \& Gatot Soepriyanto. Sistem Akuntansi Sektor Publik, Konsep untuk Pemerintah Daerah .Jakarta : Salemba Empat. 2003.

Hakim,M.F. 2018. Analisis Kinerja Keuangan pada Pemerintah Daerah Kabupaten Sleman Tahun Anggaran 2010 - 2016.Skripsi, (Online). (https://dspace.uii.ac.id) Diakses 15 Oktober 2019.

Halim,A. 2007. Akuntansi Sektor Publik: Akuntansi Keuangan Daerah. Jakarta: Salemba Empat.

Halim,A. 2008. Auditing (Dasar-dasar Audit Laporan Keuangan).Yogyakarta : Unit Penertbit dan Percetakan STIM YKPN.

Harry Saputra Liando, David Paul Elia Saerang,Inggriani Elim :Analisis Kinerja Keuangan Pemerintah Kabupaten Kepulauan Sangihe menggunakan Metode Value For Money, Jurnal EMBAVol.2 No.3 September 2014, Hal. 1686-1694.

Ibnu,S. 1986. Pokok-Pokok Kebijaksanaan, Perencanaan, Pemrograman dan Penganggaran Pembangunan Tingkat Nasional. Jakarta: CV. Rajawali.

Indra Bastian, 2007.Audit Sektor Publik. Jakarta : Salemba Empat.

Irham,F. 2011. Analisis Laporan Keuangan. Lampulo: ALFABETA.

Jumingan. 2006. Analisis Laporan Keuangan, Cetakan Pertama. Jakarta: PT. Bumi Aksara.

Madismo. 2006. Perwujudan Transparansi dan Akuntansi Publik Melalui Akuntansi Sektor Publik: Suatu Sarana Good Governance. Jurnal Akuntansi Pemerintah Volume 2 (1).

Mahmudi, 2010.Manajemen Keuangan Daerah. Jakarta: Penerbit Erlangga.

Mahsun,M. 2012. Pengukuran Kinerja Sektor Publik. Yogyakarta: BPFE.

Mangkunegara,A.A.A.P. 2000. Manajemen Sumber Daya Manusia. Bandung: PT. Remaja Rosdakarya.

Mardismo, 2002.Otonomi dan Manajemen Keuangan Daerah. Yogyakarta: Penerbit Andi.

Peraturan Menteri Dalam Negeri Nomor 13 Tahun 2006. Tentang Pedoman Pengelolaan Keuangan Daerah.

Sugiyono, 2016.Metode Penelitian Kuantitatif, Kualitatif dan R\&D. Bandung: PT. Alfabet.

Sutrisno, 2008.Manajemen Keuangan Teori, Konsep dan Aplikasi. Yogyakarta :Ekonisia.

Tanjung, A.H. 2006. Akuntansi Keuangan Daerah Konsep dan Aplikasi. Bandung: Alfabeta.

Undang-Undang No. 23 Tahun 2014 Tentang Otonomi Daerah 
Undang-Undang No. 28 Tahun 2008 Tentang Pembentukan Daerah Otonomi Baru di Provinsi Sulawesi Selatan

Undang-Undang No. 33 Tahun 2004 Tentang Perimbangan Keuangan antara Pemerintah Pusat dan Daerah.

Wahidah Niken Kusumadewi, Ventje Ilat, Analisis Kinerja Keuangan Pada Pemerintah KabupatenMinahasa Utara Tahun 2012-2014, Jurnal EMBA Vol.4 No.1 Maret 2016, Hal.634-644.

Zuhri,Mdan A. Soleh. 2015. Analisis Kinerja Keuangan Pemerintah Daerah Kabupaten Kaur. Jurnal, Online (https://media.neliti.com) diakses 16 Oktober 2019. 